\title{
DUKUNGAN NUTRISI PADA PENDERITA PEMFIGUS VULGARIS DENGAN HIPOALBUMINEMIA BERAT
}

\author{
Asrini Safitri*, Suryani As'ad* \\ *Departemen Ilmu Gizi, Fakultas Kedokteran Universitas Muslim Indonesia, \\ Makassar
}

Pendahuluan

Pemfigus vulgaris adalah penyakit autoimmune berupa bula yang bersifat kronik, dapat mengenai membran mukosa maupun kulit dan ditemukannya antibodi IgG yang bersirkulasi dan terikat pada permukaan sel keratinosit, menyebabkan timbulnya suatu reaksi pemisahan sel-sel epidermis diakibatkan karena tidak adanya kohesi antara sel-sel epidermis, proses ini disebut akantolisis dapat menyebabkan kerusakan kulit dan membran mukosa sehingga dapat terjadi kehilangan cairan dan ketidakseimbangan elektrolit, infeksi, bahkan sepsis

\section{Deskripsi Kasus}

Seorang wanita umur 51 tahun, dikonsul dari bagian kulit dan kelamin dengan diagnosis pemfigus vulgaris dengan hipoalbuminemia berat. Dari anamnesis didapatkan asupan makan berkurang, Dialami sejak 3 bulan terakhir akibat nafsu makan berkurang dan mual. Tidak muntah. Cepat lapar tapi juga cepat kenyang. Nyeri menelan tidak ada. Namun ada rasa nyeri saat mengunyah makanan pada lidah dan mulut terutama bagian luar. Saat ini tidak demam, riwayat demam 2 minggu lalu.Penurunan berat badan ada tapi besarnya tidak diketahui. Buang air besar:pagi ini 1 kali, warna coklat, konsistensi lunak.,Buang air kecil: kesan lancar.Luka pada hampir seluruh badan. Dialami sejak 2-3 bulan yang lalu. Awalnya berupa gelembung berisi air di daerah dada, leher, punggung belakang, kemudian pecah. Semakin hari semakin banyak dan meluas dan disertai nyeri. Nyeri menelan ada, terdapat banyak luka pada mulut. Riwayat berobat di RS Pare namun tidak ada perbaikan. Punggung mengering, lipatan dan 
leher masih basah. Pasien tidak demam. Status dermatologis : Regio Generalisata, Eff : Bula, erosi, ekskoriasi, krusta, madidans.

Pemeriksaan fisis, ditemukan anemis pada konjungtiva, luka pada bibir dan lidah, Edema minimal pada ekstremitas inferior. Wasting tidak ada. LLA $23 \mathrm{~cm}$. Dari pemeriksaan laboratorium ditemukan $\mathrm{Hb}$ 7,6 gr/dl, TLC 487/ $\mu 1$, albumin $1,8 \mathrm{gr} / \mathrm{dl}$, protein total $2,9 \mathrm{gr} / \mathrm{dl}, \mathrm{GDS}$ 124. Pasien diberikan $1900 \mathrm{kkal} / \mathrm{hari}$. Diberikan tinggi protein 1,5 gram $/ \mathrm{kgBB}$, karbohidrat $55 \%$ dan lemak $29 \%$ terutama PUFA.Diberikan suplementasi ekstrak ikan gabus,vitamin B1,vitamin B6 dan vitamin B12.vitamin C $1000 \mathrm{mg}$, vitamin A $20.000 \mathrm{IU}$, curcuma, zinc $20 \mathrm{mg}$, EPA $400 \mathrm{mg}$. Perawatan selama 15 hari dengan memberikan terapi nutrisi yang disesuaikan dengan kondisi dan toleransi pasien serta ditingkatkan bertahap hingga mendekati KET. Terjadi perbaikan yang ditandai dengan LLA $23,8 \mathrm{~cm}$, terjadi perbaikan terhadap luka.Pemeriksaan laboratorium $\mathrm{Hb}$ $11,7 \mathrm{mg} / \mathrm{dl}$, TLC $2.440 / \mu \mathrm{l}$, albumin 3,3 gr/dl, protein total $6,9 \mathrm{gr} / \mathrm{dl}$. Pada akhir pengamatan pasien dapat beraktivitas normal, selera makan sangat membaik. Luka mulai membaik

\section{Kesimpulan}

Dengan penatalaksanaan nutrisi yang baik akan mampu mempertahankan dan meningkatkan status nutrisi sehingga pasien mampu menghadapi stres metabolik yang akan dihadapi dan memperbaiki kualitas hidupnya

Kata Kunci :pemfigus vulgaris, gizi kurang, hipoalbuminemia 
